\title{
Entrepreneurship Skills Acquisition and the Benefits amongst the Undergraduate Students in Nigeria
}

\author{
Dr (Mrs.) Florence A. Undiyaundeye \\ Department of Eccde, Federal College of Education, Obudu \\ undiyaundeyeflorence@gmail.com
}

Phone: No. +234 805742 2724/+234 8064127750

Ekpungu Anselm Otu

Dept Og Gse, Fce Obudu

\begin{abstract}
There is this colonial mentality among the first generation graduates in Nigeria where there has been a craze for white collar office work alone. In recent times, the Nigeria graduates have faced a lot of frustrations from lack of achieving the white collar job so to speak. This paper is advocating the adoption of re-positioning the economic development and entrepreneurial drive for job creation, wealth creation and global competitiveness of Nigeria youths and graduates. The basic truce of this paper is to enhance a match between theory and practice as facilitated by research and development centers in the Nigerian universities to serve as a technology laboratory and incubate entrepreneurship skills. The entrepreneurship education as a compulsory course in some Nigerian university system is actually viewed as a means to empower the youths through entrepreneurship education. The paper critically looked at the role of entrepreneurship education. The purpose is to equip the individual and create the mindset to undertake the risk of venturing into applying the knowledge and skills gotten from school. Other issues like the provision of individuals with enough training to enable creativity and innovation relevant to skill acquisition to encourage self-employment and self-reliant were x-rayed. Some techniques like industrial training exercise, workshop and seminar, excursion as a vehicle in the youth empowerment and eradication of poverty and extreme hardship were mentioned. Challenges like inadequate funding, lack of training personnel and men availability of equipment were identified as issues facing entrepreneurship education. Recommendations like entrepreneurial base curriculum at all levels of education, provision of enabling environment for entrepreneurial development required for economic advancement and youth empowerment should be the key focus in Nigeria for youths and graduates from various tertiary schools as applicable.
\end{abstract}

Keywords: Skill acquisition, poverty eradication, youth empowerment, entrepreneurship education and graduate job challenges.

\section{Introduction}

It is common knowledge that about $80 \%$ of graduates in most Nigerian universities find it hard to get employment every year. This is largely due to the curricula of the universities and other tertiary schools with emphasis on training for whitecollar jobs. Nigeria has an estimated population of 170 million people (NBS, 2004 and Ojo, Abayomi \& Odozi, 2014). This population is endowed with abundant human and natural resources and a favourable geographical location in the world map. The current global financial crisis has impacted negatively on the macro and micro levels of the Nigerian economy. In the present, this situation has posed serious challenges and threats to government and a great number of the citizens. Nigeria like other developing countries is faced with a number of problems ranging from youth and graduate unemployment, high level of poverty, insurgency, conflict and diseases, insincerity, over dependency on foreign made goods, low economic growth and development, lack of capacity and required skills to move the economy forward and urbanization. Unemployment has become a major problem bedeviling the lives of youths and graduates causing frustration, depression, dejection and dependency on family members and friends. The high level of unemployment among this population in Nigeria has contributed to the high rate of insecurity, violence in elections and poverty (Ajufo, 2003 \& Simkovic 2012). The National Population Commission (2013), Ojo, Abayomi \& Odozi (2014) and Awogbenle and Iwamadi (2010) are of the view that sixty four (64) million of the Nigeria youths are unemployed while one million six hundred thousand (1.6million) are 
underemployed bringing the total of youths population to eighty (80) million representing youth population. When this percentage is deducted from the total population of Nigeria then you would agree with me that repositioning entrepreneurship education in our schools would salvage this gap as it were against the white collar job ambitions,

One of the possible causes for this lack is that the education in Nigeria addresses only output end of capacity development solving problem. In addressing the input and therefore, a complimentary approach is needed. In developed economies or industrialized economies for instance, the education system emphasizes the trail of inquiry-discovery application in teaching and students to perceive problems (including societal problems) as challenges and opportunities that can be turned into goods and services of commercial value (Adejimola \& Olufumilayo, 2009, Giwa 2000, and Adeyemi 2006). One of the approaches to achieve the contending in Nigeria is teaching and research at entrepreneurship and innovation centres by universities and other tertiary institutions and the promotion of universities-private sector collaboration. This should involve developing the capacity of staff and students in entrepreneurship and innovation, engaging in outreach activities with small and medium enterprises through such interventions as business incubators. Training entrepreneurs and conducting research and consultancies are inevitable as it pertains to entrepreneurial, industrial and economic growth in Nigeria.

\section{The Concept of Entrepreneurship Education}

The entrepreneurship education refers to many things to variation of people as applicable to their values and observations of what it means to them. Nwabuama (2004) sees entrepreneurship education as the identification of the general characteristics of entrepreneurs and how potential entrepreneurs can be trained in management techniques needed for effective performance of persons for long time service of an organization after the acquisition of occupational skills. For Ebele (2008), entrepreneurship education is the teaching of knowledge and a skill that enables the students to plan, start and run their own business. In the view of Olawolu and Kaegon (2012), entrepreneurship education prepares youths to be responsible and entering individuals who become entrepreneurial thinkers by exposing them to real life learning experiences where they will be required to think, take risks, manage circumstances and incidentally learn from the outcome. Okereke and Okorafor (2011) assert that entrepreneurship education is a potent and viable tool for self-empowerment, job and wealth creation. Entrepreneurship education entrails teaching students, learners and would-be business men, equipping the trainees with skills needed for teaching responsibility and developing initiatives of prospective trainees (Ezeani, 2012). Entrepreneurship education entails philosophy of self reliance such as creating a new cultural and productive environment promoting new sets of attitudes and culture for the attainment of future challenges (Ogundele, Akingbade and Akinlabi, 2012).

Entrepreneurship education is the type of education which has the ability to impact on the growth and development of an enterprise through technical and vocational training. Actually entrepreneurship education has its peculiar learning and teaching approaches. Solomon (2007), highlighted entrepreneurship education teaching approaches to include business then writing, lecture by professionals, case studies, chose programme supervision and experimental learning, visit of experts on site. Above all the approaches of teaching and learning entrepreneurship education mentioned above, the experimental teaching which involves pragmatic approach seem to be the best base on the studies of (Solomon and Tarabisky 1999). Young people can build confidence in their abilities to become entrepreneurs and be empowered in their future as a result of varieties of entrepreneurial activities provided through education.

\section{The Purpose of Entrepreneurship Education}

Entrepreneurship education as posited by Paul (2005) and Nwalado (2012) structured the following as the main purpose of Entrepreneurship education:

- $\quad$ Provide the young graduates adequate training that will enable them to be creative and innovative in identifying great business opportunities.

- To offer functional education to the youths to enable them to be well empowered and self-reliant people in their own right.

- To serve as catalyst for economic growth and development. 
- $\quad$ To offer tertiary institution graduates with adequate training in risk management to make learning outcome feasible.

- $\quad$ To reduce the high rate of poverty and insecurity and violence.

- $\quad$ To create job and employment opportunities for its citizenry.

- $\quad$ To reduce the rural-urban migration

- $\quad$ To provide the young graduates with enough training skills and support that will enable them to establish a career in small and medium size business.

- To incubate the spirit of perseverance in the youths and adults which will enable them to persist in any business venture they embark on.

- To create a smooth transition from tradition to modern industrial economy.

\section{The Concept of Youth Empowerment}

The term youth is the time of life when the individual is young especially the period between childhood and maturity of the early period of existence, growth or development. The word youth, adolescent, teenage and young persons are usually used interchangeably. A youth generally refers to a time of life that is neither childhood nor adulthood but rather somewhere in between. Youth is an alternative word to the scientifically oriented adolescent and common terms of teen or teenage. Jega (2012) define youth as a special group of people with strong stamina and passion for realizing some goals and purpose. Different countries define the word youth relating to their objectives, conditions and realities existing on ground based on history, contemporary socio-economic and political issues as need to be addressed. For this, different parameters and variables are used in defining their youths in the country. In Nigeria the National Youth Development Policy refers to all young persons of age $18-33$ years as youths. This category is present in most cultures, the most volatile and yet the most vulnerable segment of the population, socio-economically, emotionally and in other aspects. The youths share certain characteristics that distinguish them from other generation. These characteristics include: impatience for change, zealousness, radicalism, rebellions, curiosity, hard work, ego and ambition. The youths are the engine and actualize of national development if their mindsets are channeled in the right direction.

Springing from the need to enable young people to have a say in decisions which affect them and to have heard voices; This give rise to young people who have economic, social and cultural advancement of their countries and to gain selffulfillment. Young people are empowered when they acknowledge that they have or can create choices in life, are aware of implications of these choices, make an informed decision freely, take action based on that decision and accept responsibility for the consequences of that action.Youths empowerment is an attitudinal, structure and cultural process whereby young people gain the ability, authority and agency to make decisions and implement change in their own lives and the lives of other people including youths and adults (Ezeani, 2012). Youth empowerment means creating and supporting the enabling conditions under which young people can act on their own behalf, on their own terms, rather than at the direction of others. These enabling conditions includes economics and social base, political will, adequate resource allocation and supportive legal and administrative frameworks, a stable environment of equality, peace and democracy and access to knowledge, information and skills and a positive value system.

\section{Challenges Facing Entrepreneurship Education and Youth Empowerment in Nigeria}

Entrepreneurship education has received a boost as a source of job creation, empowerment for the unemployed and the underemployed in a globalized economy worldwide. For Nigeria, the following reasons hinder Entrepreneurship education:

- Poor entrepreneurial culture,

- $\quad$ Lack of fund.

- $\quad$ Poor knowledge based economy and low spirit of competition.

- $\quad$ Lack of entrepreneurial teachers, materials and equipment.

- $\quad$ Non-inclusion of entrepreneurship practical programme in the school curricula.

- Poor societal attitude to technical and vocational education development.

- Inadequate facilities and modern equipment for teaching and learning.

- Insensitivity of government to enterprise creation and expansion strategy. 
- Poor plan and execution of processes of action.

- Isolated or pockets of ineffective programmes and management in competencies.

- Inadequate parental care.

- Breakdown of family values and indiscipline.

- Political manipulation of youth organizations.

Despite the difficult situation and the dire need for change, the government has done little to reduce the misery and frustration of its citizenry, fostering hopelessness in the majority of young people who have resorted to any means including crime to succeed in life. The youth are expected not to involve in crime but to channel their energy towards the development of our dear country Nigeria.

\section{Entrepreneurship Skills Creation for Undergraduate Studies}

The wheel of development of any country lies on the shoulder of how productive and creative the youths are. Parents, teachers and government have the obligation to ensure that the youths are empowered. There is apparent economic depression in the midst of our so-called oil boom in Nigeria. The problem with Nigerian educational programmes is the too much emphasis on the value on certificate rather than the skills required in the career. In other words, the individual struggle hard through any means to attain the golden fleece which is the certificate rather than the knowledge and skills which should make them self-reliant. Hence, it is hope and rightly too, that in the first place government should encourage a diversification of the economy through adequate support for private establishment and practical acquisition of skills in higher institutions. For this, education should be refined with a view to create and enhance the supply and entrepreneurship in the youth initiatives and activities.

Apart from the entrepreneurship curriculum, there are other specific activities which can be carried out with a view to create an entrepreneurship skills creation in the Nigerian tertiary schools. Some of them as (Okojie 2008, Osibanjo, 2006 and Ememe 2011), highlighted:

- Establishment of entrepreneurship development centres.

- Establishment of small and medium scale establishment resources centres.

- Establishment of some clubs in the tertiary schools.

- $\quad$ Organize business plan competitions

- Introduce networking events through workshops, seminars, symposia, lectures and stakeholders where cross fertilization of ideas could occur.

- Identify entrepreneurship business opportunities.

- There should be role model interaction and mentoring to deliver motivated discussions in form of key notes or lectures.

- Industrial visits and excursion for on site field trip like students of mass communication could visit media houses, medical students could visit pharmaceutical company and education students could visit modern schools with facilities to mention but a few.

- $\quad$ Make the students master at least one vocation that can guarantee self-reliance.

- Inculcate in the students the knowledge of the modern information communication and technology that will enable them to interact effectively with their immediate and distant environment.

- To fashion out modalities for setting up a career/entrepreneurship centre where students can be counselled and guided on the right career to follow after their graduation.

- There should be a school based enterprise where students identify potential business plan, create and operate small business by using the school as a mini incubator.

- There should be some form of innovative for students who have done their practical work well during site supervision. This will motivate them to establish businesses after school graduation.

\section{Conclusion}


Entrepreneurship education has been clearly observed here as a vehicle to ride off the endemic problem of poverty, hunger and youth empowerment. When the youths are provided with the right raining in practice, they explore opportunities in their immediate environment instead of chasing shadows in the cities. The development of Entrepreneurship education will go a long way in creating employment, give young people the opportunity to develop their enterprising skills, empowering the young to be job creators and not job seekers through the provision of necessary skills and knowledge to raise their output, income and wealth. Entrepreneurship education would also contribute to improve the image and highlight the role of entrepreneurs in the society. The current industrial decay and the subsequent unemployment crisis among the Nigerian graduates have been traced to the theory-oriented university programmes and certificate frenzy compiled with the celerial mentality of golden fleece.

The economic situation of Nigeria needs re-engineering in order to strategically reposition Nigeria as the true leader of Africa. I strongly recommend curriculum review, sensitization, advocacy and mobilization of support for Entrepreneurship education, programme focus and funding together with the political will and stability of the government in order to achieve the goals and the policy thrusts of the Federal Government of Nigeria.

\section{References}

[1] Abayomi, A.A, Ojo, L.B \& Odozi, A.F (2014). Entrepreneurship education: A viable tool for youth empowerment in Nigeria: Academic Journal of Interdisciplinary studies. Vol. 3 No. 4 pp 11 - 19 July.

[2] Adejimola, A.S \& Olufumilayo, T.O (2009). Spinning off an entrepreneurship culture among Nigerian University students: Prospects and Challenges: African Journal of Business management. Vol. 3 (3) pp 80-88 March.

[3] Adeyemi, K.S (2006). Opportunities for entrepreneurship in Nigeria: A handout.

[4] Akingbade O.A \& Akinlabi, H.B. (2012). Entrepreneurship training and education as strategic tools for poverty alleviation in Nigeria. American International Journal of Contemporary Research Vol.2 (1) January.

[5] Ajufo, B.I \& Simkovic, C.G.E (2013). Challenges of youth unemployment in Nigeria. Effective career guidance as a panacea. African Research: An International multi-disciplinary Journal. Ethiopia 7(1) 28 pp 307-321 January

[6] Amogbenle, A.C \& Iwamadi, K.C (2010). Youth empowerment entrepreneurship development programme as an interaction mechanism. African Journal of Business management 4(6) $831-833$.

[7] Ebele, O.P (2008). Introduction to interpreneurship Education. A Paper presented at OMAH Rivers Chapter $2^{\text {nd }}-3^{\text {rd }}$ November

[8] Ememe, (2011). Entrepreneurship education in the eastern Nigeria: Implication for Higher Education Administration. Unpublished Ph.D dissertation. University of Port-Harcourt.

[9] Ezeani, N.S (2012). Tackling unemployment through vocational education, science education development institute. University of Nigeria.

[10] Ezeani, N.S (2012). The teacher and skills acquisition at Business Education Curriculum at University level in Nigeria. International Journal of Ghana 3 (1) $30-33$.

[11] Giwa, R.F (2000). Investment and trade opportunities: A sectoral approach. A Paper presented at a seminar on Nigeria at 40: Towards Economy Revival Sept. 27 - Oct 2.

[12] Jega, B.N. (2012). Nigerian Youth and National Developmetn Sahara Reporters March 26, $28-59$.

[13] Nwabuama, E.C (2004). Information Technology (IT) and Enhancement of Entrepreneurship education in secretarial studies programme in polytechnics in Nigeria: A Paper presented at the Association of Business Education UNICAL Calabar $2^{\text {nd }}-6^{\text {th }}$ November

[14] Nwalado, I.G. (2012). Entrepreneurship in education Concepts and Constraints. African Journal of Education and Development Studies 4(1) $196-207$

[15] Okojie, J.A. (2008). Policy Framework and strategy for entrepreneurship development. For Nigerian Universities. A paper presented at the National Sensitization workshop on entrepreneurship development in Nigeria Universities organized by National University Commission. Abuja $21^{\text {st }}$ May.

[16] Okoroafor, B. (2011). Entrepreneurship and Wealth Creation the Nigerian Accountant. April/June

[17] Olawolu, O.E \& Kaegon, LES (2012). Entrepreneurship education as a tool for youth empowerment through Higher education for global work place in Rivers. A paper presented at seventy Regional Conference on Higher Education for a globalized world organized by HERPNET: holding at University of Ibadan Nigeria. $10^{\text {th }}-21^{\text {st }}$ September. 
[18] Olumole, T. (2003). A synopsis of discipolines and careers Akure, Ondo State Nigeria. Orteeyz Ltd

[19] Osibanjo, O. (2006). Concept of Entrepreneurship and innovation for 200-level students at the University of Ibadan, January 18.

[20] Paul, A. (2005). Positioning Nigeria for effective response to the challenges emerging technology and globalization in Vanguard, December 4

[21] Simkovic, M. (2012). Risk based students loan available at social science research network. (SSRN) Accessed on July 2012.

[22] Solomon, E. \& Tarabisky, D.F (1999) Entrepreneurship theory process and practice $6^{\text {th }}$ edition Ohio: South Western 